\title{
MENGATASI STRES AKADEMIK DALAM PEMBELAJARAN MATEMATIKA MELALUI PENGUATAN SELF ESTEEM PESERTA DIDIK
}

\author{
Oleh: Widodo Winarso \\ Dosen IAIN Syekh Nurjati Cirebon \\ Email : widodo_ppsstain@yahoo.co.id
}

\begin{abstract}
ABSTRAK
Sebagian besar peserta didik dalam menjalani kegiatan pembelajaran matematika di sekolah, seringkali merasakan stres. Stres yang dialami peserta didik cenderung disebabkan oleh perasaan tidak mampu yang dimiliki peserta didik itu sendiri dalam menghadapi berbagai situasi, kejadian dan tantangan yang ada selama kegiatan pembelajaran matematika berlangsung. kondisi tersebut membuat peserta didik merasa tidak nyaman dalam menerima materi ajar. Pencapaian tujuan pembelajaran tidak dapat mencapai hasil maksimal, jika pendidik memaksakan pada situasi tersebut. hal yang perlu diperhatika oleh pendidik yakni kemampuan peserta didik untuk membangun dan mempertahankan kondisi fisik maupun psikis selama pembelajaran matematika berlangsung. Berdasarkan konsekuensi tersebut, self esteem yang tinggi dalam diri peserta didik dapat menghilangkan atau mengurangi stres yang dirasakan peserta didik akibat berbagai tekanan yang dialami peserta didik berkaitan dengan pembelajaran matematika di sekolah.
\end{abstract}

\section{A. PENDAHULUAN}

Sebagian besar masyarakat pasti bercita-cita memiliki kehidupan yang lebih layak, baik untuk kehidupan sekarang maupun untuk masa depan kelak. Usaha yang dilakukan tentu tidak lepas dari upaya mendapatkan pendidikan yang setinggi-tingginya. Hal ini dikarenakan ijazah yang merupakan lambang hasil akhir dari serangkaian proses pendidikan formal, seringkali menjadi syarat seseorang dalam memperoleh pekerjaan. Suatu pendidikan itu sendiri menurut pendapat Syah (1999:3) diartikan sebagai usaha sadar yang dilakukan untuk menumbuhkembangkan potensi sumber daya manusia melalui kegiatan pengajaran atau pembelajaran.

Kegiatan pembelajaran yang dilaksanakan di sekolah, memuat berbagai mata pelajaran yang harus dipelajari peserta didik. Salah satu mata pelajaran yang dianggap penting adalah matematika. Dapat dikatakan demikian, terbukti dengan semakin banyaknya tempat-tempat les maupun privat matematika yang tersedia. Suatu lapangan pekerjaan hanya bisa terus berjalan jika banyak masyarakat yang menginginkan atau membutuhkannya. Hal ini menunjukkan betapa penting mata pelajaran matematika sehingga peserta didik atau orang tua peserta didik rela untuk menghabiskan tenaga, waktu serta uang lebih untuk peserta didik mempelajari matematika. 
Banyak peserta didik yang menganggap matematika sebagai pelajaran yang menakutkan. Hal ini disebabkan oleh berbagai macam faktor, misalnya anggapan tentang pendidik matematika yang galak atau rumus yang harus dihafal. Walau itu hanya persepsi saja, tapi pada kenyataannya hal ini membuat kebanyakan peserta didik merasa terintimidasi dengan pelajaran matematika. Di beberapa sekolah, terkadang tingkat kepintaran peserta didik juga ditentukan oleh pelajaran matematika. Semakin cepat peserta didik memahami materi pelajaran matematika, maka peserta didik tersebut dikategorikan pada golongan peserta didik pandai. Sebaliknya, apabila peserta didik cenderung lamban menangkap materi pelajaran, maka peserta didik tersebut dimasukkan pada golongan peserta didik kurang pandai. Golongan inilah yang sering menganggap matematika sebagai sesuatu yang menakutkan karena selain harus bersusah payah dan berusaha lebih dalam mengerjakan soal matematika, tetapi juga harus tahan dengan berbagai anggapan negatif orang-orang di sekitar tentang kemampuan peserta didik tersebut dalam matematika. Hal seperti itu seolah semakin mempertegas mata pelajaran matematika sebagai pelajaran yang menakutkan bagi peserta didik.

Berbagai persepsi negatif tentang matematika tentunya membawa dampak negatif pula bagi peserta didik itu sendiri. Dalam proses pembelajaran, idealnya seorang peserta didik haruslah merasa nyaman jika ingin materi pelajaran yang diajarkan pendidik bisa dipahami dengan baik. Namun dalam kenyataannya, kebanyakan peserta didik justru merasa stres bahkan pada saat pelajaran matematika baru akan dimulai. Peserta didik tersebut tiba-tiba menjadi gugup, tubuh berkeringat banyak, detak jantung meningkat, serta muncul perasaan takut selama jam pelajaran matematika berlangsung. Peserta didik tersebut menjadi kurang dapat menyerap materi pelajaran, tidak bisa fokus dan berkonsentrasi pada apa yang diajarkan pendidik. Peserta didik yang seperti demikian, selama pelajaran matematika berlangsung, justru disibukkan dengan berbagai perasaan takut dan cemas yang dirasakan. Hal-hal seperti itu merupakan sebagian kecil gejala stres yang terjadi pada seseorang dalam kegiatan pembelajaran (Mumpuni dan Wulandari, 2010:41).

Stres merupakan suatu bentuk respon seseorang, baik secara fisik maupun mental, terhadap suatu perubahan di lingkungannya yang dirasakan mengganggu dan mengancam. Segala macam bentuk stres pada dasarnya disebabkan oleh seseorang yang kurang mengerti akan keterbatasan-keterbatasannya. Selanjutnya, ketidakmampuan untuk melawan keterbatasan inilah yang akhirnya menimbulkan rasa cemas, gelisah dan rasa bersalah yang merupakan gejala-gejala stres (Rasmun, 2004:1). 
Tidak bisa dipungkiri, sebagian besar alasan utama peserta didik menganggap matematika menakutkan, pelajaran yang susah dan hanya membuat stres karena kurang mampunya mereka dalam memahami pelajaran matematika itu sendiri. Perasaan tidak mampu ini kemudian berkembang dalam diri mereka, sehingga muncul berbagai persepsi negatif yang selanjutnya memicu rasa stres dalam menghadapi pembelajaran matematika. Di sinilah betapa besarnya peranan self esteem seseorang terlihat.

Hal tersebut sejalan dengan pendapat Wheeler (2007:3) yang mengemukakan bahwa stres melibatkan rentetan peristiwa, dimulai dengan sesuatu yang dianggapnya sebagai ancaman/sumber bahaya. Ancaman ini mungkin memang nyata atau mungkin juga hanya suatu pemikiran. Saat seseorang menilai kesungguhan dari suatu ancaman, langkah berikutnya pada respon stres adalah menilai kemampuannya untuk menangani ancaman itu. Ini melibatkan bagaimana perasaannya tentang hal itu serta seberapa besar keyakinan diri yang dimiliki untuk dapat mengatasinya. Di mana rasa keyakinan diri merupakan komponen utama dalam self esteem.

Chomaria (2009:16) menjelaskan bahwa sesungguhnya setiap manusia, dari segala tingkat jenjang usia membutuhkan stimulus atau rangsangan untuk berkembang. Tanpa adanya suatu stimulus, perkembangan manusia baik secara fisik maupun psikis tidak optimal. Stimulus yang berupa tantangan merupakan sesuatu yang sering muncul saat kegiatan pembelajaran di kelas. Tantangan yang harus dihadapi ini seringkali membuat peserta didik merasakan ketegangan dalam dirinya yang biasanya dicirikan dengan detak jantung meningkat atau muncul perasaan cemas. Hal seperti demikian masih merupakan sesuatu yang wajar dan sering terjadi. Yang menjadi perhatian lebih adalah bagaimana peserta didik menanggapinya. Tanggapan peserta didik terhadap tantangan ini dapat bersifat positif maupun negatif. Hal ini banyak ditentukan oleh seberapa besar self esteem peserta didik. Tracy (2007:50) mengemukakan bahwa self esteem adalah kemampuan seseorang menghargai diri sendiri, menghargai kelebihan dan mengetahui kekurangan yang dimiliki. Kalimat yang tepat untuk mendefinisikannya yaitu seberapa besar seseorang menyukai dirinya sendiri.

Seseorang dengan self esteem yang tinggi akan senantiasa menanggapi berbagai situasi dan kejadian yang dialaminya secara positif, sehingga segala tantangan yang terjadi selama kegiatan pembelajaran dianggap sebagai sesuatu yang menjadikannya lebih bersemangat dan terpacu untuk belajar lebih giat.

Berbeda dengan peserta didik yang mempunyai self esteem yang rendah yang cenderung menanggapi berbagai situasi dan kejadian di sekitarnya secara negatif. Peserta 
didik yang seperti demikian selalu menganggap dirinya tidak berdaya, sehingga ketika menghadapi tantangan peserta didik tersebut cenderung memaknai tantangan itu sebagai sesuatu yang mengganggu, mengancam dan bahkan menganggapnya sebagai tekanan (Clemes, dkk, 1995:13). Perasaan tertekan inilah yang membuat stres dalam diri peserta didik semakin tinggi. Menurut Desmita (2012:299) peserta didik yang mengalami tingkat stres yang tinggi dapat menimbulkan kemunduran prestasi.

Lebih lanjut, self esteem yang tinggi pada peserta didik juga membentuk pribadi yang pantang menyerah dan penuh percaya diri sehingga peserta didik tidak mudah putus asa saat dihadapkan pada masalah yang harus dihadapi, dalam hal ini misalnya adalah soal-soal matematika yang membutuhkan kosentrasi dan pemahaman lebih. Hal ini dikarenakan orang yang memiliki self esteem yang tinggi, merasa yakin dengan kemampuan yang dimiliki, merasa bahwa dirinya efektif hingga percaya bahwa mampu serta dapat mencapai keberhasilan (Branden, 2005:60).

Self esteem yang tinggi juga tentunya membuat peserta didik tidak mudah merasa tertekan saat belajar matematika di kelas. Perasaan tertekan cenderung menimpa peserta didik dengan self esteem yang rendah. Ketakutan yang mendominasi pemikiran peserta didik selama pelajaran matematika berlangsung, membuat peserta didik merasa terganggu dan terancam walau tanpa alasan yang jelas. Apabila itu terjadi terus-menerus, peserta didik akan semakin merasa stres dan cenderung sebisa mungkin menghindari pelajaran matematika. Di sinilah kaitan antara self esteem yang dimiliki peserta didik dengan stres akademik yang dirasakan peserta didik dalam pembelajaran matematika.

\section{B. Konsep Self Esteem}

"Self" berarti diri dan "esteem" jika diartikan ke dalam bahasa Indonesia mempunyai arti penghargaan, menghargai. Maka jika kedua kata tersebut digabungkan mempunyai arti penghargaan diri atau menghargai diri sendiri. Secara umum istilah self esteem diartikan sebagai penilaian seseorang untuk dirinya sendiri, evaluasi global seseorang mengenai dirinya (Santrock, 2007:63).

Penilaian terhadap diri peserta didik perlu tumbuh dan berkembang. kondisi tersebut menjadikan peserta didik mengenal batas kemampuan dan kelemahan dirinya dalam proses pembelajaran di kelas. Mata pelajaran matematika memberikan tantangan, bahkan memberikan tekanan lebih besar secara psikologis di banding mata pelajaran lain. Kemampuan menyelesaian soal matematika membutuhkan energi yang lebih besar. Situasi tersebut akan terhambat jika peserta didik tidak pandai-pandai dalam mengelola 
diri nya sendiri. kemampuan menghargai diri sendiri sangat penting untuk memotivasi dalam menjaga kondisi pisik dan psikis peserta didik.

Coopersmith (dalam Branden, 2005:17) menyatakan bahwa makna dari penghargaan atas diri adalah evaluasi yang dibuat oleh individu dan dipertahankan. Itu mengungkapkan suatu persetujuan atau ketidaksetujuan, dan mengindikasikan suatu sejauh mana seorang individu percaya bahwa dirinya mampu, penting, sukses dan layak. Singkatnya, penghargaan atas diri adalah penilaian pribadi tentang kelayakan yang dinyatakan di dalam sikap individu terhadap dirinya.

Penjelasan tersebut memiliki makna bahwa dalam self esteem terkandung kepercayaan diri yang tinggi. Tidak hanya meyakini kemampuan yang dimiliki, tetapi juga senantiasa berpikir positif sehingga melahirkan keyakinan bahwa dirinya dapat sukses dan memang layak untuk mendapatkan kesuksesan dan keberhasilan.

Branden (2005:42) mendefinisikan self esteem atau penghargaan atas diri sebagai keyakinan di dalam kemampuan diri untuk berpikir dan menghadapi tuntutan hidup; juga keyakinan di dalam hak untuk bahagia, perasaan berharga, layak, diizinkan untuk menilai kebutuhan dan keinginan diri serta menikmati hasil dari kerja keras yang telah dilakukan.

Keberhasilan dalam pencapaian cita-cita masa depan, dapat terbangun melalui finalisasi dari hasil pembelajaran di sekolah. Matematika memberikan modal berfikir kepada peserta didik dalam menyelesaikan masalah pembelajaran. Bahkan tidak hanya itu, kemampuan berpikir logis menjadikan peserta didik dapat berpikir divergen untuk menerjemahkan arti kehidupan.

Menurut Powell (2004:8) memberikan definisinya tentang self esteem yang mempunyai arti bagaimana seseorang berpikir, berpendapat serta perasaan yang dimiliki terhadap dirinya sendiri. Hal ini mengacu kepada bagaimana pendapat orang itu tentang kemampuannya, penampilannya, hubungannya dengan orang sekitar, serta harapanharapannya untuk masa depan. Self esteem dapat memberi pengaruh pada kesehatan, karir dan hubungan sesorang, serta bagaimana bertindak dengan berbagai permasalahan yang dihadapi. Self esteem merupakan faktor penting dalam membuat seseorang merasa bahagia.

Kebahagian peserta didik akan tergambar dalam tercapainya tujuan pembelajaran. Rasa percaya diri dalam mengerjakan latihan matematika timbul dari dalam diri peserta didik, selain itu dukungan lingkungan sekitar juga berpengaruh terhadap penguatan pada Self esteem seseorang. kemampuan hal tersebut, dapat membantu peserta didik dalam memenuhi keterbatasannya. 
Sejalan dengan kontek di atas, menurut Tracy (2007:50) mengartikan self esteem dengan satu kalimat yaitu "Seberapa besar peserta didik menyukai dirinya sendiri". Karena semakin seseorang menyukai dirinya sendiri, maka semakin baik pula orang tersebut akan bertindak dalam pembelajaran matematika. Sementara itu, Desmita (2011:165) memberikan pendapatnya bahwa self esteem merupakan evaluasi individu terhadap dirinya sendiri secara positif atau negatif. Evaluasi individu tersebut dilihat dari penghargaan yang diberikan terhadap eksistensi dan keberartian dirinya.

Kemampuan mengevaluasi diri sendiri tergantung kepada peserta didik itu sendiri. kreativitas berpikir dalam belajar matematika, Pengalaman Peserta didik dalam menyelesaikan permasalahan matematika memberikan sumbangsih terhadap penguatan dalam self esteem seseorang. selain itu perasaan yang peka terhadap lingkungan belajar juga dapat memberikan penguatan pada pembentukan self esteem.

Seperti halnya Clemes, dkk (1995:7) mengemukakan bahwa rasa nilai diri seseorang berasal dari seluruh pikiran, perasaan dan pengalaman yang telah orang tersebut kumpulkan sepanjang hidupnya. Pendapat bahwa pandai atau tidak, merasa kecewa atau senang, menyukai diri sendiri atau tidak, berbagai kesan, penilaian dan pengalaman yang dimiliki dari diri sendiri dapat menambah perasaan senang tentang nilai diri seseorang atau sebaliknya memberikan perasaan tidak nyaman atau kecewa.

Self esteem merupakan komponen emosional dalam kepribadian seseorang, dan faktor yang penting dalam menentukan bagaimana seseorang berpikir, merasa, serta bertingkah laku. Tingkat self esteem seseorang ditentukan oleh seberapa cocok self image (performansi dan perilaku saat ini) dengan self idea (gambaran seperti apa orang tersebut akan bertingkah laku jika berada dalam kondisi terbaiknya). Di dalam alam bawah sadar, orang tersebut akan selalu membandingan performansi aktual dengan performansi ideal yang dimiliki.

\section{Komponen Self Esteem}

Terdapat beberapa komponen dalam pembentukan self esteem pada peserta didik. menurut Branden (2005:60) menjelaskan bahwa self esteem terdiri atas dua komponen utama yang saling berkaitan, yaitu keyakinan diri dan rasa harga diri. Keyakinan diri mempunyai arti keyakinan dalam berfungsinya pemikiran seseorang: dalam kemampuan untuk berpikir, dalam proses di mana menilai, memilih, memutuskan, keyakinan dalam kemampuan untuk memahami fakta-fakta yang berada dalam batasanbatasan minat dan kebutuhan orang tersebut, kepercayaan diri dan keandalan diri. Sementara itu, rasa harga 
diri mempunyai arti suatu sikap tegas menuju hak untuk hidup dan berbahagia, kenyamanan dalam menegaskan pemikiran, keinginan dan kebutuhan. Perasaan nyaman dan bahagia dengan segala yang ada pada diri kita, baik kelebihan maupun kekurangan.

Sementara itu, terdapat beberapa komponen self esteem pada peserta didik menurut Awlawi (2013:185) antara lain:

1) General self esteem, berkaitan dengan aktifitas tertentu atau keterampilan dan perasaan harga diri dan kepercayaan diri serta persepsi keseluruhan individu dari nilai mereka.

2) Social self esteem, aspek yang mengacu pada persepsi individu terhadap kualitas hubungan dengan teman sebaya serta kemampuan untuk terlibat dalam interaksi interpersonal individu hidup dalam dunia sosial.

3) Personal self esteem, berkaitan dengan bagaimana orang lain melihat dirinya sendiri. Berdasarkan konsep di atas, dapat dimaknai bahwa komponen dalam pembentukan self esteem dapat bersumber dari diri sendiri dan dari luar individu. Pertama komponen yang bersumber dari dalam diri, merupakan pembentukan kondisi seseorang melalui kemampuan seseorang itu sendiri untuk mengolah rasa (hati), pikiran dan pengalaman selama kegiatan pembelajaran berlangsung. Sedangkan komponen yang bersumber dari luar, merupakan pembentukan kondisi seseorang melalui persepsi orang lain terhadap dirinya kearah penguatan jati diri yang positif.

\section{Konsep Stres Akademik}

Belajar merupakan suatu proses kegiatan aktif peserta didik dalam membangun makna dan pemahaman, maka peserta didik perlu diberi kemampuan yang memadai untuk melakukan proses itu. Artinya memberikan kemampuan pada peserta didik untuk berpikir, merasa dan membangun pengalaman ketika peserta didik menghadapi masalah dalam pembelajaran matematika.

Matematika merupakan salah satu bidang studi yang masih dianggap sulit oleh peserta didik, baik bagi peserta didik pendidikan dasar maupun tingkat yang lebih tinggi. Salah satu penyebab utama kesulitan tersebut adalah bahwa dalam matematika banyak mengandung konsep-konsep yang abstrak. Penguasaan konsep-konsep abstrak memiliki tingkat kesulitan yang lebih tinggi dibandingkan dengan penguasan konsep-konsep kongkrit, karena untuk memahami konsep tersebut, peserta didik membutuhkan peranan daya pikir yang lebih kuat untuk memecahkan masalah-masalah yang tidak dapat teramati secara langsung. kondisi tersebut memicu pada kekuatan atau ketahanan 
psikologis peserta didik dalam belajar matematika. sehingga dimungkinkan peserta didik mengalami stress akademik dalam pembelajaran matematika.

Secara umum stres merupakan bentuk reaksi tubuh terhadap situasi yang terlihat berbahaya atau sulit. Suatu kondisi yang disebabkan adanya ketidaksesuaian antara situasi yang diinginkan dengan keadaan biologis, psikologis atau sistem sosial individu tersebut. Dengan kata lain, seringkali stres terjadi karena adanya keinginan yang tidak terpenuhi, harapan yang tidak sesuai rencana, segala keadaan yang tidak seperti yang diinginkan, ketidaksesuaian antara harapan dan kenyataan. Artinya, stres merupakan reaksi psikologis terhadap tuntutan hidup yang tidak sesuai dengan harapan dan membebani kehidupan seseorang serta mengganggu kesejahteraan hidupnya (Mumpuni dan Wulandari, 2010:2).

Kesenjangan antara kenyataan dan harapan menjadikan sikap peserta didik untuk tidak siap menerima materi pembelajaran. Sikap tersebut dapat menghambat peserta didik dalam pencapain tujuan pembelajaran matematika. Peran pendidik sebagai fasilisator pembelajaran seharusnya dapat memberikan stimulus positif terhadap gajala psikologis yang terjadi di peserta didik. Namun hal yang terpenting adalah kemampuan peserta didik untuk bangkit dan mempertahan diri jauh lebih penting dari itu semua. respon yang terbangun atas dasar kesenjang tersebut perlu disikapi dengan baik agar psikologis peserta didik dapat terjaga.

Menurut Santrock (2003:557) berpendapat bahwa stres merupakan respon individu terhadap keadaan atau kejadian yang memicu stres (stressor) yang mengancam dan mengganggu kemampuan seseorang untuk menangani atau menghadapinya. Sementara itu, Rasmun (2004:9) mendefinisikan stres sebagai respon tubuh yang tidak spesifik terhadap setiap kebutuhan tubuh yang terganggu, suatu fenomena universal yang terjadi dalam kehidupan sehari-hari dan tidak dapat dihindari. Stres member dampak secara total pada individu yaitu terhadap fisik, psikologis, kognitif, sosial dan spiritual.

Dampak yang sifatnya multi dimensi tersebut akan berpengarauh pada peserta didik itu sendiri. Bahkan selain itu, hubungan sosal antara peserta didik akan tergangu pula. Berdasarkan pendapat Busari $(2012: 138)$ bahwa stres terjadi ketika terdapat tuntutan pada seseorang di mana tuntutat tersebut dianggap melampaui kemampuan penyesuaian dirinya. Lebih lanjut, Lazarus (dalam Lubis, 2009:17) mengemukakan bahwa stres merupakan bentuk interaksi antara individu dengan lingkungan yang dinilai individu sebagai sesuatu yang membebani atau melampaui kemampuan yang dimiliki serta mengancam kesejahteraan. 
Sedangkan Wilks (2008:107) menyebutkan bahwa stres akademik adalah stres yang diakibatkan oleh tuntutan akademik yang dirasakan melampaui kemampuan adaptasi dari individu. Selain itu Verna, dkk. (dalam Desmita, 2012:291) mendefinisikan stres akademik sebagai akibat dari tuntutan sekolah, yaitu stres peserta didik yang bersumber dari tuntutan sekolah.

Tuntutan akademik yang dimaksud yaitu lebih menfokuskan pada tuntutan tugastugas sekolah dan tuntutan dari pendidik. Sementara itu, Desmita (2012:291) menyebutkan bahwa stres akademik merupakan perasaan tidak nyaman yang dialami oleh peserta didik akibat adanya tuntutan sekolah yang dinilai menekan, sehingga memicu terjadinya ketegangan fisik, psikologis, dan perubahan tingkah laku.

\section{E. Tanda-Tanda Peserta didik Mengalami Stres Akademik Dalam Pembelajaran Matematika}

Pendidik dalam menjalankan kewajibanya sebagai pengajar harus memeiliki kepekaan yang baik. Pendidik harus peka terhadap perubahan prilaku maupun sikap dari peserta didik. Kondisi peserta didik yang mengalami stres akademik dapat terlihat melalui kedua hal tersebut. Adapun tanda-tanda yang mungkin terjadi pada peserta didik ketika mengalami stres akademik dapat dilihat dari empat aspek, yaitu fisik, tingkah laku, emosi dan kognitif.

Pertama Tanda fisik stres, diantaranya keluar keringat secara berlebihan, berkeringat dingin pada tangan, kesulitan bicara, sakit kepala dan jantung berdebar atau detak jantung meningkat. Kedua tingkah laku stres, diantaranya tidak suka bersosialisasi, tidak peduli, dan meningkatnya perilaku negatif. Ketiga tanda kognitif stres, diantaranya pelupa atau sukar mengingat serta sukar konsentrasi. Keempat tanda emosi stres, diantaranya mudah marah, agresif, mudah merasa cemburu dan mudah cemas (Mumpuni dan Wulandari, 2010:44).

Wulandari dan Theis (2012:26) menyebutkan bahwa stres dalam pembelajaran matematika adalah kondisi stres yang dialami oleh peserta didik akibat adanya tuntutan sekolah mengenai pelajaran matematika yang dinilai menekan.

Pembelajaran matematika menyuguhkan konsep-konsep yang abstrak, sehingga peserta didik banyak mengalami kesulitan dalam menyelesaikan permasalahan pembelajaran matematika. pola pembimbingan baik sifat akademik maupun diluar akademis harus dilakukan oleh pendidik. Kedua bimbingan tersebut sekiranya dapat membantu peserta didik dalam membangun self Esteem. 


\section{F. Kaitan antara Self Esteem dengan Stres Akademik Peserta didik dalam Pembelajara Matematika}

Terdapat keterkaitan antara self Esteem dengan stres akademik yang dialami oleh peserta didik dalam pembelajaran matematika. menurut Lazarus (dalam Lubis, 2009:17) membagi stres ke dalam dua bentuk yaitu distress dan eustress. Dalam pembelajaran matematika di kelas, distress atau stres negatif adalah stres yang dirasakan peserta didik akibat menganggap situasi dan tantangan selama kegiatan pembelajaran matematika merupakan sesuatu yang mengganggu dan mengancam. Sementara Eustress atau stres positif yaitu stres baik atau stres yang tidak mengganggu dan justru menganggap tantangan yang terjadi selama kegiatan pembelajaran matematika merupakan sesuatu yang membuatnya lebih bersemangat dalam belajar.

Dalam kegiatan pembelajaran matematika di kelas, perbedaan masing-masing individu dalam bereaksi terhadap stressor erat kaitannya dengan self esteem yang dimiliki oleh tiap peserta didik. Branden (2005:47) menyebutkan bahwa peserta didik dengan self esteem yang tinggi yang dicirikan dengan selalu memandang apa yang dialami sebagai sesuatu yang positif, akan cenderung menghadapi stressor yang muncul selama kegiatan pembelajaran matematika sebagai sesuatu yang mengharuskannya untuk lebih bersemangat. peserta didik tersebut pun berhasil menghilangkan stres ringan yang sempat dialaminya dan mengubah stres menjadi sesuatu yang positif. Sebaliknya, peserta didik dengan self esteem yang rendah yang senantiasa merasa dirinya sebagai seseorang yang tidak berdaya akan cenderung semakin merasa tertekan yang selanjutnya membuat peserta didik tersebut selalu merasa takut dan cemas sepanjang kegiatan pembelajaran matematika. Perasaan stres yang dirasakan pun semakin besar.

\section{G. Penutup}

Kegiatan pembelajaran matematika di kelas seringkali memberikan berbagai tantangan pada peserta didik, di mana hal ini dilakukan para pendidik dengan harapan peserta didik dapat lebih aktif dalam mengikuti kegiatan pembelajaran matematika di sekolah. Tantangan-tantangan yang diberikan pendidik ini, tidak jarang justru menimbulkan ketegangan dalam diri peserta didik. Rasa tegang ini biasa diikuti dengan perasaan takut dan cemas.

Matematika merupakan salah satu mata pelajaran yang seringkali dianggap sulit oleh peserta didik. Keharusan dalam menghafal rumus dan melakukan banyak 
perhitungan dalam mengerjakan soal biasanya merupakan alasan peserta didik menganggap matematika sulit. Terlebih lagi, rumus tersebut juga cenderung bersifat baku dan tentunya tidak bisa diubah seenaknya. Jawabannya pun sudah pasti, peserta didik tidak bisa mengarangnya. Bahkan cara untuk mengerjakannya pun seringkali harus sesuai dengan ketentuan yang ada. Hal inilah yang menambah perasaan tegang yang dirasakan peserta didik saat tantangan yang diberikan pendidik dalam pembelajaran matematika adalah mengerjakan soal matematika.

Namun demikian, terdapat dua cara bagaimana peserta didik menanggapi ketegangan yang dirasakan selama pembelajaran matematika tersebut yaitu menanggapi ketegangan itu sebagai sesuatu yang positif dan menanggapi ketegangan itu sebagai sesuatu yang negatif. Hal ini bergantung pada seberapa besar self esteem yang dimiliki oleh peserta didik.

Seorang peserta didik yang memiliki self esteem yang tinggi yang dicirikan dengan selalu memandang segala sesuatu secara positif tidak akan merasa terintimidasi dengan matematika. Peserta didik tersebut akan selalu yakin dengan kemampuan yang dimiliki dan akhirnya ketegangan yang sempat dirasakan pun justru membuat peserta didik tersebut merasa harus lebih bersemangat lagi dalam belajar agar dapat menyelesaikan soal matematika yang diberikan pendidik.

Berbeda dengan peserta didik yang memiliki self esteem yang rendah. Peserta didik dengan self esteem yang rendah cenderung menanggapi segala sesuatu yang terjadi di sekitarnya secara negatif. Peserta didik seperti ini, saat merasakan ketegangan akibat tantangan yang ada selama kegiatan pembelajaran matematika berlangsung, akan semakin merasa takut dan cemas yang akhirnya menyebabkan peserta didik merasakan stres. 


\section{DAFTAR PUSTAKA}

Awlawi, Addahri Hafidz. 2013. Teknik Bermain Peran Pada Layanan Bimbingan Kelompok untuk Meningkatkan Self Esteem. Jurnal Ilmiah Konseling. Vol. 2

Branden, Nathaniel. 2005. Kekuatan Harga Diri. Batam: Interaksara

Busari. 2012. Identifying Difference in Perceptions of Academic Stress and Reaction to Stressors Based on Gender among First Year University Students. International Journal of Humanities and Social Science. Vol. 2

Clemes, H, dkk. 1995. Bagaimana Meningkatkan Harga Diri Remaja. Jakarta: Binarupa Aksara

Chomaria, Nurul. 2009. Tips Jitu dan Praktis Mengusir Stress. Jogjakarta: DIVA Press

Desmita. 2011. Psikologi Perkembangan Peserta Didik. Bandung: Remaja Rosdakarya

Lubis, N. L. 2009. Depresi: Tinjauan Psikologi. Jakarta: Kencana

Mumpuni, Yekti dan Ari Wulandari. 2010. Cara Jitu Mengatasi Stres. Yogyakarta: Andi

Powell, Jillian. 2004. Self Eseem. London: Franklin Watts

Rasmun. 2004. Stres, Koping dan Adaptasi. Jakarta: Sagung Seto

Santrock, John W. 2003. Adolescence: Perkembangan Remaja. Jakarta: Erlangga

Santrock, John W. 2007. Perkembangan Anak. Jakarta: Erlangga

Syah, Muhibbin. 1999. Psikologi Pendidikan. Jakarta: Logos Wacana Ilmu.

Tracy, Brian. 2007. Change Your Thinking, Change Your Life: Bebaskan Potensi Dahsyat Anda Untuk Kesuksesan Yang Tak Terbatas. Bandung: Kaifa

Wilks, Scott E. 2008. Resilience amid Academic Stress: The Moderating Impact of Social Support among Social Work Students. Advances in Social Work. Vol.9

Wheeler, Claire Michaels. 2007. 10 Simple Solutions To Stress. Oakland: New Harbinger 